\title{
Movement ecology, breeding, diet and roosting behavior of barn owls (Tyto alba) in a transboundary conflict region
}

\section{Gabriel Rozman}

University of Haifa

Ido Izhaki

University of Haifa

Alexandre Roulin

Universite de Lausanne

Motti Charter ( $\nabla$ mcharter@geo.haifa.ac.il )

University of Haifa https://orcid.org/0000-0003-3861-6356

\section{Original Article}

Keywords: Movement ecology, Reproductive success, Transboundary conflict zones, GPS wildlife tracking, Roosting behavior

Posted Date: February 5th, 2021

DOl: https://doi.org/10.21203/rs.3.rs-161889/v1

License: (9) (1) This work is licensed under a Creative Commons Attribution 4.0 International License. Read Full License

Version of Record: A version of this preprint was published at Regional Environmental Change on February 27th, 2021. See the published version at https://doi.org/10.1007/s10113-021-01758-2. 


\section{Abstract}

Transboundary frontiers often contain wildlife habitats that are fractured by geopolitical borders, which could have adverse effects on the wildlife that inhabit those areas. We examined the movement, breeding, roosting and diet of 15 GPS-tagged barn owls (Tyto alba) along the Israeli-Jordanian and IsraeliPalestinian Authority borders. Our results showed that $80 \%$ of the barn owls hunted across the border. On average, the owls engaged in 5.4 hunting trips per night, $16 \%$ of which were cross-border excursions, and they crossed the borders as frequently as expected randomly, highlighting the importance of wildlife protection on all sides. Hunting movement, rather than cross-border activity, had an effect on the annual reproductive success and diet composition. Specifically, female owls that spent more time at the nest and engaged in longer distance hunting trips had higher reproductive success. $80 \%$ of the females roosted outside of the nest box at a median distance of $908 \mathrm{~m}$ (range $=199-4,112 \mathrm{~m}$ ). Only $13.3 \%$ of the owls (2/15 owls) roosted across the border. These results increase our understanding of the movement, breeding, and roosting behavior of a non-migratory avian raptor. However, a serious lack of cooperation and communication between bordering countries hampers our ability to understand the full effects of differing environmental policies on a species that knows no borders.

\section{Introduction}

Transboundary frontiers are landscapes artificially fractured by geopolitical borders that rarely contain an ecological foundation (Liu et al. 2020). These boundaries often overlap with endemic species' habitats (Fowler et al. 2018) and may consist of physical barriers along international borders, such as the USMexico border wall. Alternatively, there may be no physical barrier, but the two countries may have vastly different policies regarding wildlife management and conservation (Arrondo et al. 2018). Furthermore, transboundary frontiers can occur in conflict zones, increasing the risk to the wildlife that inhabit those areas. Risks can be physical, such as threats from gun fire and landmines, as well as intangible, such as lessened chance of cooperative management and conservation between the two countries in conflict (Liu et al. 2020). Additionally, transboundary regions may occur between developed and developing countries, the latter typically suffering from greater economic constraints, lack of an ability to enforce proper environmental practices (Liu et al. 2020) and especially in rural areas, a dependence of exotic bush meat as a dietary supplement (De Merode et al. 2004). Additionally, there may be a disparity in the extent of research conducted in both regions (Boitani and Ciucci 2009). Cultural differences and stigmas may also have an impact on the wildlife. For example, in Africa, endangered pangolins (Smutsia temminckii) are eaten in order to improve good luck and protect against spiritual forces (Boakye et al. 2014) and in Brazil, owls are killed because they are a sign of bad luck and death (Santos and Santos 2019). Therefore, movement of species between these regions could put them at heightened risk.

Movement is a fundamental characteristic of life (Nathan et al., 2008). Organisms move for many reasons including to search for food, mates and breeding sites. Animals differ in how far and how often 
they move. Studies related to the management and conservation in transboundary regions often examine large mammals such as the sun bear (Helarctos malayanus) along the China-Myanmar border (Li et al. 2017)) and the grey wolf (Canis lupus) along the Sweden-Norway border (Boitani and Ciucci 2009). However, there is a notable lack of studies on non-migratory species that can travel long distances on a daily basis (Lambertucci et al. 2014). Non-migratory avian species exemplify this category because they are likely undeterred by physical barriers such as fences and may regularly travel between regions. The main threats to these species in transboundary areas are less related to habitat fragmentation caused by physical barriers, but rather to differing environmental policies and even cultural stigmas. Differing environmental policies can include regulation of pesticide uses in agricultural regions (Ecobichon 2001), conservation practices, and illegal wildlife trade and prevention of poaching (Liu et al., 2020). For example, Arrondo et al. (2018) found that differential sanitary regulations affected cinereous vulture (Aegypius monachus) movement between Portugal and Spain.

Transboundary movement may also have implications on reproductive success. To date, the majority of studies examined the effect on breeding population size (Tucakov et al. 2006) rather than on individual reproductive success. A study conducted by Wolf et al. (2006) showed that sea birds with high connectivity between the US and Mexico contained high levels of population extirpations when breeding in Mexico compared to the US, due to a lack of protection.

Many countries regulate the types of pesticides that farmers use in order to prevent adverse environmental effects such as secondary poisoning of non-target species (Ecobichon 2001). Avian predators that inhabit transboundary regions may spend time foraging in regions with little to no pesticide regulation and therefore put themselves and their young at a heightened risk of fatal secondary poisoning (Ratcliffe 1970; Fry 1995; Martínez-Padilla et al. 2017). Additionally, since diet quality may affect reproductive success in birds (Korpimäki 1992; Charter et al. 2015; Tompkins et al. 2017), regions with different environmental practices may vary in prey abundance (Charter et al. 2009) and composition, thereby impacting the reproductive success of the birds that forage there. Furthermore, birds that roost in areas with cultural stigmas against them or high levels of poaching and illegal trade may be at heightened risk as well.

The goal of this study was to examine the movement, breeding, roosting and diet of a non-migratory avian raptor in a transboundary region where the countries are in conflict, contain different environmental policies and cultural stigmas, and where one country is considered developed (Israel), while the bordering regions are considered developing (Jordan and the Palestinian Authority, thereafter the PA). Thus, this study enables us to better understand the implications that transboundary regions have on species that 
frequent both areas on a daily basis as well as increase our knowledge regarding the movement, roosting, breeding and diet of a non-migratory avian raptor.

Barn owls (Tyto alba) breeding along the Israeli-Jordanian and Israeli-PA borders provide a good opportunity to examine the affect that transboundary conflict regions may have on the movement, breeding, roosting and diet of a species that frequent both sides of the border. From the moment Israel was established in 1948 it was at war with neighboring Jordan, and although the two countries now enjoy diplomatic relations after a peace treaty was signed in 1994, they are often strained (Eisenberg and Caplan 2003). Regarding scientific cooperation, researchers in Palestinian and Jordanian institutions are discouraged from any sort of collaboration with their Israeli counterparts (Thomas 2013). The relationship between Israel and the neighboring PA has been much more tumultuous, with frequent spats of violence, such as the first and second intifadas from 1987-1993 and 2000-2005. This explains why scientific cooperation remains minimal (Thomas 2013). Israel and both Jordan and the PA employ vastly different environmental policies, with Israel allowing only one type of regulated rodenticide for agriculture (1080, Sodium fluoroacetate), while both Jordan and the PA permit multiple types of potentially harmful rodenticides that are unregulated (Abd Rabou 2020), including second generation anticoagulants (Glausiusz 2018). Similarly, bans on illegal wildlife trade and poaching are much less restricted or enforced in Jordan and the PA (Eid and Handal 2018). Additionally, in the PA barn owls are considered bad omens and are therefore frequently poached but are also trapped and sold in pets shops and markets (Abd Rabou 2020).

For several reasons, barn owls are a well-suited bird species for examining the relationship between movement ecology, breeding, roosting and diet. First, they breed in nest boxes (Charter et al. 2010) making them accessible to trap and monitor. Second, their body size enables fitting tracking devices for extended periods. Third, barn owls are common in agricultural regions due to an abundance of rodents, which, puts them at heightened risk to secondary poisoning from rodenticide use. Additionally, they have a large variation in their reproductive success (Martínez and López 1999; Charter et al. 2015; Roulin 2020), and they are opportunistic feeders specializing in small mammals and their diets often vary according to region (Gubanyi et al. 1992; Klok and De Roos 2007) thereby affecting their reproductive success (Klok and De Roos 2007; Charter et al. 2018)

Barn owls are frequently used in nest box schemes both in conservation (Petty et al. 1994) and as biological pest control agents of rodents in agriculture (Meyrom et al. 2009; Kross et al. 2016; Wendt and Johnson 2017; Peleg et al. 2018). Despite the usefulness of nest boxes, they may potentially act as "ecological traps" (Klein et al. 2007). This may be the case along the Israeli-Jordanian and Israeli-PA borders (Roulin et al. 2017), where owls are drawn to nest boxes supplied by Israeli farmers, but may be 
exposed to harm due to poaching and secondary poisoning while hunting or roosting on the Jordanian and PA side of the border.

Most barn owl movement studies have relied on radio telemetry (Seel et al. 1983; Hegdal, Paul L. Blaskiewicz 1984; Hafidzi and Hamzah 2003; Naim et al. 2012; Kan et al. 2014; Thomsen et al. 2014; Hindmarch et al. 2017), which has several drawbacks: low temporal resolution (cannot create movement tracks), a near nest box bias, and also require actively searching for the tracking signal (man power). Recently, some studies have started to use more advanced GPS (Massa et al. 2015) or similar type tags (Weller et al. 2016) to study microbiome (Corl et al. 2020), habitat use (Castañeda 2018), communal breeding (Séchaud et al. 2020) and sexual segregation during (Rozman 2020) in barn owls. However, to date, no studies have been published on whether barn owl movement is related to reproductive success, diet, cross border movement and roosting behavior.

In the present study, we examined movement ecology, breeding, diet and roosting behavior of barn owls in a transboundary conflict region by attaching GPS tags. We hypothesize that (1) barn owls breeding in the transboundary region show no preference or avoidance in hunting between the differing regions because they are undeterred by the physical barrier along the borders, (2) increased utilization of habitat, less restrictive and enforced environmental policies, and negative cultural stigmas on the Jordanian and PA side have a negative effect on the owls' reproductive success, and (3) diet composition is affected by the extent of transboundary activity because differing regions and agricultural practices often support different prey species composition.

Regardless of being in a transboundary region, this study enables us to examine the behavioral ecology of a non-migratory avian raptor in terms of its foraging, breeding, roosting and diet. We further hypothesize that: (4) Foraging behavior will impact reproductive success such that increased provisioning and nest defense will positively contribute to reproductive success and (5) foraging behavior, specifically distances and frequency of hunting trips will influence prey diversity and composition.

\section{Materials And Methods}

\section{Study site}

The study area was located in the Jezreel Valley $\left(32^{\circ} 38^{\prime} \mathrm{N}, 35^{\circ} 8^{\prime} \mathrm{E}, 57.7 \mathrm{~m}\right.$ a.s.I.) and Beit-Shean Valley $\left(32^{\circ} 30^{\prime} \mathrm{N}, 35^{\circ} 30^{\prime} \mathrm{E} ;-221\right.$ a.s.I.) and is mostly made up of cattle fodder (wheat, sweet corn, alfalfa, clover, vetch and oats), grain crops and seeds (wheat and sweet corn), spices and herbs (oregano, hyssop, basil, 
and dill), olive orchards and small villages. Nest boxes were added in the area as part of using barn owls as biological pest control agents against rodents (Meyrom et al. 2009; Peleg et al. 2018).

\section{Tracking devices}

During the 2014-2015 breeding seasons, 15 female barn owls (6 in 2014 and 9 in 2015) breeding in Israel were trapped inside nest boxes and their sex determined given that only females have a brood patch that is used for incubation. The length of their wings was measured to the nearest $\mathrm{mm}$ and their tarsus length to the nearest $0.1 \mathrm{~mm}$. Body mass was recorded to the nearest gram, and a Gypsy 4 GPS tag by Technosmart (Guidonia, Italy, length $=32.1 \mathrm{~mm}$, width $=22.3 \mathrm{~mm}$, antennae $=4 \mathrm{~cm}$, weight $=13 \mathrm{~g}$ ) was attached to the owls using a Teflon harness. Localizations were set at one-minute intervals. A little over a week later, all owls were re-trapped using a specially-designed patio trap, and the tags were removed from the owls and the data downloaded. The number of tags we could add was limited both by budget (cost of tags and man power to capture the owls) and difficulties to re-capture adults. Specifically, we were able to re-capture a maximum of 2-3 owls per night because of the amount of time till capture (could take up to 6 hours in a single night and if unsuccessful we would return another night) and after capture the time to add the tags (45 minutes per owl). We added GPS tags only to females because males were much more difficult to capture. Specifically, unlike females that we were able to capture the first time inside the nest boxes while roosting and then re-capture using the patio traps, males roosted outside of the nest boxes and would therefore need to use the patio trap twice. Unfortunately, owls become trap shy after being captured using the patio traps once and we therefore chose to concentrate our effort only on females. The owls were tracked on average for 9.2 days $(S E=1.1$ and range $=4-18$ ) resulting in a mean of 5,186 localizations per owl (SE $=653$ and range $=2,178-10,313$ ) and a total of 77,784 localizations. See Fig. 1 for an image of study area, nest box distribution and an example of barn owl tracks.

\section{Nest box monitoring}

All the nest boxes were monitored between five to eight times (for descriptive statistics see Table 1) in order to determine the number of nestlings when the oldest sibling was 53 days old (hereafter "reproductive success"). Laying date was defined as the date at which the first egg was laid, and was determined by measuring the wing length of the oldest sibling and then back-calculating laying date from the age of the oldest nestling plus an average incubation period of 32 days (Roulin 2004). Days after first laying pair was calculated as the number of days a given pair laid its eggs after the first breeding pair for each year (hereafter known as LD). When the 15 females were tagged, the age of the oldest nestling was 
on average 21.5 days ( $\mathrm{SE}=1.5$ and range $=11-28$ days), and the number of days the eggs were laid after the first laying pair was on average 16.3 days $(S E=4.5$ and range $=0-61)$.

\section{Pellet samples}

After the tags were removed, 11 fresh pellets were randomly collected for each pair. We selected 11 pellets because as shown in an earlier study, diet analyzed from 11 or from 50 from pellets gives similar results (Charter et al. 2012). The pellets were analyzed by extracting mandibles, skulls, and femurs to identify the species of prey to calculate the percentage of house mice (Mus musculus, hereafter, mice) and Levant voles (Microtus guentheri, hereafter, voles) in the diet, the two most frequent prey species. Prey diversity is the Shannon Diversity Index of small mammal diversity and was calculated for each nest using the R-package vegan (Oksanen et al. 2008).

\section{Statistical analyses}

\section{Data processing}

$94 \%$ of the GPS-localizations were linked to 4-8 satellites and all localizations that were linked to three or fewer satellites were removed according to Gustin et al. (2018). However, this study diverged from that study (Gustin et al. 2018) that used 6-8 satellites because they also required altitude; we did not use altitude in our analysis. We therefore determined that at least four satellites were sufficient in providing reliable localizations.

All the localizations were imported into $\mathrm{R}$ (version 3.6.2) and for each localization the distance to the nest box was calculated using the $\mathrm{R}$ package Geosphere (Hijmans 2019). All points that were within a 100meter radius of the nests were classified as being at the nest because there were no potential roosting sites around the nest boxes enabling us to set a relatively high threshold. All other points were classified as hunting. Roosting sites were determined using the R function AdpFixedPoint (Schiffer, I. pers comm.) that looked for clusters of localizations (5 or more points), with a flight speed of zero and within a 100meter radius. Clusters that were observed between 5:00-19:00 were considered to be roosting sites. Additionally, using QGIS we created polygons representing either Israel or the PA and Jordan combined 
(hereafter Other). The tracking localizations were overlaid on the polygons using the R package sp (Pebesma and Bivand 2005) and the territory (Israel or Other) was determined for each localization.

Movement variables were calculated per night from the tracking data in $\mathrm{R}$ (version 3.6.2) and each night was averaged over the tracking period. Median displacement is the median of the Euclidean distance from each hunting localization to the nest box. Foraging trips is the sum excursions based on when the owl left the 100-meter buffer around its nest and then returned within that 100-meter buffer. To account for cases in which the owl passed the nest without truly returning, the following foraging trip still belonged to the previous foraging trip if the owl spent less than 180 seconds within the 100-meter buffer because the owl most likely did not actually return to the box with prey. The percent of time hunting is the sum of the time intervals between points when the owl was classified as hunting divided by the sum of the total time interval. The kernel estimation and utilization distribution (Worton 1989) was used to estimate the home-range (hereafter known as HR) using the R-package adehabitatHR (Calenge 2006) with the following parameters: the ad hoc method for smoothing and a HR at the 99th percentile level. All localizations that were classified as at the nest were excluded in order for the HR to be based solely on hunting movement. Hunting locations were determined by using the kernel estimation and utilization distribution described above, but with a HR at the $50^{\text {th }}$ percentile level to isolate the hunting hotspots. All $\mathrm{HR}$ variables were calculated per tracking period rather than per night.

Additionally, we calculated the extent of cross-border activity pertaining to the movement variables. The distance of the nest box to the border varied (Table 1). If an owl crossed the border during a hunting trip, then that trip was considered to be a cross-border excursion. The percentage of trips in which an owl crossed the border was calculated by dividing the number of cross-border trips by the total number of trips. Percentage of time hunting in Other territory is the sum of the time intervals the owl spent hunting across the border divided by the sum of the total hunting time interval. Percentage of HR in Other territory is the area of the HR across the border divided by the total HR.

Finally, variables related to the nesting, roosting and hunting sites were calculated. These included the Euclidean distance of the nest site to the border, nest site to the roosting sites, roosting sites to the border, hunting locations to the roosting sites and hunting locations to the nest. Any roosting site that was within a 100-meter radius of the nest boxes was considered as roosting at the nest because there were no other roosting sites within $100 \mathrm{~m}$ from the nest boxes. 


\section{Cross-border activity}

Cases where the dependent variables did not follow a normal distribution were transformed to be between 0-1 to fit a beta distribution and generalized linear mixed models (GLMM) with a beta distribution using R package GLMMTMB (Brooks et al., 2017) were performed (from now on GLMMTMB). For all models, year was included as a random factor.

Three generalized linear mixed models (GLMMTMB) were performed to examine the effect of the distance of the nest to the border on the cross-border percentage of HR, hunting trips and time hunting.

Finally, we built a null model to test whether the owls crossed the border more or less than expected randomly. See appendix for detailed description of procedure.

\section{Factors affecting reproductive success}

We performed three generalized linear mixed models (GLMMTMB) to check the relationship between reproductive success (dependent variable) and (1) cross-border activity, (2) hunting movement, diet and LD and (3) distances between roosting, nesting and hunting sites. In the first analysis, distance of the nest to the border and percentage of cross-border: HR, time hunting and hunting trips, were independent variables.

In the second analysis, LD, prey diversity, median displacement, time hunting and foraging trips were independent variables. In the third analysis, mean distance of nest site to roosting site, mean distance of hunting site to roosting site, mean distance of hunting site to nest site and mean distance of roosting site to the border were independent variables. Corrected Akaike's Information Criterion values (AICc) were calculated. Models were ranked and compared using the $\triangle \mathrm{AICc}$ values $(\Delta \mathrm{i}=\mathrm{AICc}(\mathrm{i})-\mathrm{AICc}(\mathrm{min}))$. Only models that had a $\triangle \mathrm{AICc}<2$, were reported, and the model estimates, standard errors, $\mathrm{z}$-values and $\mathrm{p}$ values were included for the most parsimonious models.

\section{Roosting sites}


The effect of age of the oldest offspring on the percentage of time their mother roosted at her nest was tested by conducting a generalized linear mixed model (GLMMTMB).

\section{Factors affecting diet}

The variables used to assess diet were diversity, percentage of voles and percentage of mice in the owl's diet. The diet diversity variable followed a normal distribution (Shapiro-Wilk normality test; $w=0.912, p=$ 0.143) and three linear mixed-effects models (LMM) with a Gaussian distribution using R package Ime4 (Bates et al. 2019) were performed. Three generalized linear mixed models (GLMMTMB) were used for the percentage of mice and vole variables. The tests were conducted to examine the effect of (1) crossborder activity, (2) hunting movement and (3) number of fledglings and LD on the dependent variables. In the first analysis, percentage of cross-border: HR, time hunting and hunting trips, were independent variables. In the second analysis, median displacement, time hunting and foraging trips were independent variables. In the third analysis, LD and number of fledglings were independent variables.

\section{Results}

\section{Cross-border activity}

$80 \%$ of the owls (12/15 owls) had areas of their HR and also had foraging trips across the border (Table 1 ). Only $13.3 \%$ of the owls (2/15 owls) roosted across the border and of those two, one individual roosted across the border $83.3 \%$ of the time while the other roosted across the border $12.5 \%$ of the time (Table 1 ). We found that the distance of the nest to the border did not significantly affect the foraging trips (GLMMTMB: Est <-0.001, df = 11, SE < 0.001, z = -1.221, p = 0.222), HR (GLMMTMB: Est <-0.001, df = 11, $\mathrm{SE}<0.001, \mathrm{z}=-0.524, \mathrm{p}=0.600$ ) and time hunting (GLMMTMB: Est $<-0.001, \mathrm{df}=11, \mathrm{SE}<0.001, \mathrm{z}=$ $-0.869, p=0.385$ ) across the border. In order to test whether the owls were attracted to or avoided crossing the border, we conducted a permutation analysis, showing that owls did not cross the border more or less often than expected randomly $\left(p_{\text {rand }}=0.34\right.$, Fig. 2 ).

\section{Factors affecting reproductive success}


When assessing the effect of cross-border activity, hunting movement and distances between roosting, nesting and hunting sites (Table 1 ) on reproductive success (mean $=2.9$ fledglings per pair, SE $=0.4$ and range $=1-5$ fledglings), we found that regarding (1) the effect of cross-border activity on reproductive success, two models contained a $\triangle \mathrm{AICc}<2$. The most parsimonious model (AIC $=-37.969)$ did not contain any of the predictors (distance of the nest to the border, percentage of HR across border, time hunting across the border and foraging trips across the border), indicating no relationship between crossborder activity and reproductive success. The second model (AIC $=-36.547$, delta $=1.422)$ included distance of the nest to the border and excluded all other variables. (2) Regarding the effect of hunting movement on reproductive success, the most parsimonious model (AIC $=-45.056$ ) was the only model with a $\triangle \mathrm{AICC}<2$ and included median displacement and time hunting and it did not include LD, prey diversity and foraging trips. Reproductive success was positively related to median displacement and negatively related to time hunting (Table 2). Finally, (3) whether reproductive success was affected by the distances between roosting, nesting and hunting sites, the most parsimonious model (AIC $=-38.521)$ only included mean distance of roosting site to the border. It did not include mean distance of nest site to roosting site, mean distance of hunting site to roosting site and mean distance of hunting site to nest site. The second model ( $\mathrm{AIC}=-37.969$, delta $=0.552$ ) did not include any of the variables. We found no significant relationship between the distance of the roosting site to the border and reproductive success (GLMMTMB: Est $=0.001, \mathrm{df}=11, \mathrm{SE}=0.001, \mathrm{z}=1.433, \mathrm{p}=0.152$ ).

\section{Roosting site location}

$20.0 \%(N=3 / 15)$ of the owls roosted at their nest for all the days, $13.3 \%(N=2 / 15)$ roosted away from their nest for all the days and $66.7 \%(\mathrm{~N}=10 / 15)$ of the owls varied in the percentage of days they roosted at their nest $($ mean $=55.0 \%, \mathrm{SE}=10.0$ and range $=12.5-94.4 \%$ ). For these three groups (roosted at the nest all days, roosted away for all days and varied in the percentage of days roosting at the nest or away), the average age of the oldest nestling at the onset of tracking was 18, 27 and 22 days, respectively. The number of days that females roosted at the nest boxes was inversely related to the age of the nestlings (GLMMTMB: Est $=-0.167, \mathrm{df}=11, \mathrm{SE}=0.071, \mathrm{z}=-2.337, \mathrm{p}=0.019$ ).

The 12 owls that roosted away from the nest, either every day or a percentage of the days, roosted a median distance of $908 \mathrm{~m}(\mathrm{SE}=331$ and range $=199-4,097 \mathrm{~m})$ from the nest. $66.7 \%(8 / 12)$ of the owls that roosted away did so for multiple days and $37.5 \%$ (3/8) of those roosted in multiple locations but were consistently within a square kilometer of each other. All of the owls that roosted away from their nests in Israel did so in trees located in villages (39.1\%), in orchards $(34.5 \%)$ and in groves $(25.0 \%)(\mathrm{N}=$ 60 nights), whereas, all the roosts located in the PA were only in orchards ( $N=6$ nights). 


\section{Factors affecting diet}

When assessing the effect of cross-border activity (when an owl crosses the borders), hunting movement (all moment) and number of fledglings and LD on prey diversity (mean $=0.7, \mathrm{SE}=0.1$ and range $=0-1.3$ ), we found that (1) cross-border activity was not significantly related to percentage of foraging trips across the border and diet diversity, while the relationship with percentage of time hunting across the border and prey diversity was nearly significantly positive (Table 3). (2) For hunting movement, foraging trips was significantly positively related to prey diversity (Table 3 ) and (3) for reproductive success and LD, there was no significant relationship with prey diversity (Table 3 ).

We assessed the effect of cross-border activity, hunting movement and number of fledglings and LD on percentage of mice (mean $=20.0 \%, S E=0$ and range $=0-60.0 \%$ ) in the diet. We found that (1) regarding cross-border activity, the percentage of cross-border trips had a significant inverse effect on the percentage of mice (Table 3 ) and (2) for hunting movement, foraging trips was positively related to percentage of mice (Table 3), whereas for (3) reproductive success and LD, the most parsimonious model did not contain any of the explanatory variables. In comparison, when assessing the effect of crossborder activity, hunting movement and number of fledglings and LD on percentage of voles (mean = $50.0 \%, \mathrm{SE}=10 \%$ and range $=0-90.0 \%$ ) we found that none of the most parsimonious models included any of the explanatory variables (for details of the variables included in all the models see Table 4).

\section{Discussion}

\section{Movement data}

Unlike radio telemetry studies that had a low number of localizations, and therefore were unable to calculate tracks, the number of localizations in the present study using GPS tags $(5,186$ localizations per owl over 9 days) was much larger allowing us not only to calculate home ranges but also hunting trips. The use of GPS tracking devices is still new and the few studies that were published did not always provide basic movement data such as home range and maximum/minimum hunting distances from nest boxes. A study in Californian (Castañeda 2018 ) found that the daily maximum distance $(2,860 \mathrm{~m})$ that barn owls flew from the nest was similar to our study $\left(2,770 \mathrm{~m}^{2}\right)$ and the home range $\left(17460 \mathrm{~m}^{2}\right)$ of one owl that was tracked in Argentina (Massa et al. 2015) was within the range of our study. 


\section{Cross-border activity}

When examining the extent of cross-border activity, we found that the majority of barn owls crossed the border to hunt, whereas only two roosted across the border. These results indicate that when adding nest boxes near borders, it is important to consider implications of the owls crossing the borders. Even though there may be increased risk of hunting in regions that are less regulated, especially regarding rodenticide use (secondary poisoning), persecution due to cultural beliefs, and poaching (Abd Rabou 2020), there is complete lack of published materials on the prevalence of these threats.

The finding that hunting across the border was not related to the distance of the nest to the border indicates that owls close to the border cross it just as frequently as owls that breed further away. Furthermore, the finding that owls "know no boundaries", as observed with owls not crossing the border more or less often than expected randomly, indicates that they likely have similar hunting success on both sides of the border. The finding that distance of the nest to the border did not affect the extent of cross-border activity, as well as the finding that owls crossed the borders as expected randomly suggest that other factors affect where an owl chooses to hunt, such as inter/intraspecific competition or regional prey availability and accessibility.

These results and the fact that farmers on both sides of the border continue to add barn owls nest boxes as part of biological pest control projects are important because hunting across the border may be an ecological trap if there is a heightened risk. During the duration of the study, we did not find any evidence that the owls were poached, and we did not test the levels of toxicity that may have built up from ingesting poisoned prey. However, by examining only nests where at least one chick successfully fledged due to the logistical problems of tagging owls during the incubating and early brooding periods (when most breeding failures occur), we created a bias that may have prevented us from seeing these potentially adverse effects. Furthermore, there is also a chance that threats to the barn owls occur outside the timescale of this study, for example during the non-breeding season.

The large percentage of owls roosting in Israel despite there being abundant olive orchards and other suitable locations across the border, may be in part because their nests were exclusively on the Israeli side or due to an increased chance of disturbance while roosting across the border. Similarly, owls did not roost in villages in the PA and Jordan, despite being within the range of distances they may roost. This may be because (1) there is heightened disturbance in Arab villages, (2) the Arab villages are outside of typical hunting home-ranges, (3) the nest boxes are installed closer to Israeli villages implying that the probability of roosting within these villages is higher or (4) the sample size of owls roosting in the PA is 
low $(\mathrm{N}=2$ owls). What the results of the study do show is that owls spend time on both sides and therefore there is a need for cross-border studies in both spatial and temporal resolutions to better understand how prevalent and whether these threats affect wildlife.

\section{Factors affecting reproductive success}

We did not find any significant relationship between cross-border activity and reproductive success. Based on the potential dangers of cross-border activity, we had expected to see an effect on reproductive success. However, the chances of finding pairs that failed was slim because most nest failures occur during the incubating and early brooding periods before we were able to add tags on females. We may have created a bias that may have prevented us from seeing these potentially adverse effects because we added tags when nestlings were already 25 days, after which time most pairs successfully fledge at least one nestling. Furthermore, the effect of exposure to pesticides may be long-term (Nicolaus and Lee 1999; Mitra et al. 2011) Therefore, nestlings that have been provisioned with poisoned prey may not show any symptoms until after they have fledged.

Regarding reproductive ecology, we found that hunting movement did affect reproductive success. Owls that engaged in longer distance trips but also spent more time at the nest than away had increased reproductive success. Females that spent more time at the nest may do so because they have more nestlings. However, if there are more offspring, then that might necessitate the female being away more often in order to provision for her large family. Therefore, the ability to have more nestlings and stay longer at the nest suggests that the female is relying on her mate for provisioning, highlighting the importance of cooperation in optimizing the care for young. Sonerud et al., (2014) suggests that if the female stayed in the nest in order to handle and feed, then the male could continue foraging and therefore increase the rate of provisioning. Regarding foraging distance, a study on Lesser Kestrels (Falco naumanni) found that males engaged in many short-distance trips while females engaged in fewer longdistance trips. The authors suggested that the kestrels do so in order to avoid within-pair competition and depletion of resources (Hernández-Pliego et al. 2017). This may explain why female barn owls that flew longer distances when hunting, but also remained longer periods of time at the nest, had higher reproductive success. The positive effect of female presence at the nest and longer distance foraging on reproductive success was similarly observed in a population of breeding barn owls in another agricultural region in northern Israel (Rozman 2020).

\section{Roosting site selection}


We found that the amounts of days that females roosted at the nest boxes was inversely related to the age of the nestlings. This result suggests an importance of the female's presence during the day when nestlings are young, likely for nest defense against predators, feeding them with prey remains during the daylight hours, and brooding them on cold days. Once the offspring get older, they aggressively beg for food, inducing their mother to roost outside the nest to rest during the day before hunting at night.

The finding that the majority of owls either return to the same roosting spot or within a squared kilometer indicates the prevalence of roost site fidelity. Trees seem to be the preferred structure for roosting, likely because they provide both shade and the owls can roost there relatively inconspicuously.

To the best of our knowledge, no article has examined the distances of the nest site to the roost site. We found that owls often roost at far distances from their nests, possibly closer to hunting sites, which may indicate that as the nestlings develop, parents prioritize provisioning over nest defense. Further research is important to better understand the implications of roost site distances from nest.

\section{Factors affecting diet}

When examining the effect of cross-border activity on prey diversity, we found no significant relationship, indicating that the prey abundance and composition were likely similar on both sides of the border. However, we did find a significant inverse relationship between the percentage of cross-border foraging trips and the percentage of mice in the diet. This result does not necessarily reflect any differences in rodent population, because there is a significant inverse correlation between the percentage of crossborder trips and the number of trips (coefficient $=-0.44, p=0.001$ ). Therefore, it is not necessarily the percentage of cross-border trips that influenced the diet but rather, owls that crossed the border more frequently also engaged in fewer hunting trips. We found that owls that had more trips also had a more diverse diet and a higher proportion of mice in their diet. It is therefore likely that the number of trips, rather than cross-border activity, had more of an effect on diet. Mice are generally smaller and less energetically valuable than voles (Charter et al. 2015). Our results suggest that the raptors may compensate for the lesser nutritional value by engaging in more trips. This notion is supported in a study (Slagsvold and Sonerud 2007) that examined multiple raptor species and showed that larger prey takes longer to ingest or feed to young. Therefore, by catching smaller prey, raptors can allocate more time 
hunting but less time handling the prey. Indeed, we frequently observed that nestlings have difficulties in handling very large prey items.

\section{Conclusion}

While our results did not show any relationship between cross-border activity and reproductive success, diet diversity and hunting movement, they did indicate how frequently a non-migratory avian species may utilize both sides of transboundary regions. Limitations on the ability to assess the levels of toxins ingested, along with the duration and sample size of the study may have prevented us from seeing the serious dangers posed to raptors that forage across boundary lines. Furthermore, extended monitoring of the nestlings after they fledge could reveal possible long-term adverse effects. This highlights the critical need for cooperation and data sharing between border countries. Even though poaching, trapping and poisoning has been reported on the Jordanian and PA side of the border (Abd Rabou 2020), we have a serious lack of knowledge of what happens to barn owls that are breeding in those areas. Additionally, owls that are ringed in Israel and recovered postmortem across the border are also mostly not reported. Sharing this type of information is crucial when assessing the effects that differing environmental policies, such as rodenticide use, may have on the survival and fitness of the predators that hunt there.

The finding that "barn owls know no borders" highlights the need of transboundary cooperation in researching, managing and protecting wildlife even in conflict areas. Here, we studied a resident species, but because the Middle East is also a major flyway for migrating birds (Newton 2010), the same conservation issues (poisoning, poaching, wildlife trade) are also of international importance. Even though human conflict may stem from political, religious or economic rifts, our study suggests the dire need for governments to put the politics aside in order to protect shared natural resource such as wildlife. Lastly, more research is needed to determine not only the movement of animals, but also the effects of pesticides use and poaching of wildlife that live in transboundary areas between countries.

Aside from the effect of transboundary activity, the results of this study increase our understanding of the movement, breeding, diet and roosting behavior of non-migratory raptors. Advances in tracking technology have enabled us to uncover the relationship between hunting movement and diet composition by revealing a connection between the number of hunting trips and prey size. In addition, they have enabled us to obtain a deeper view into how movement relates to reproductive success. Finally, studies on roosting site selection generally focus on the type of roosts (i.e. trees, structures, burrows). Advanced tracking technology has enabled us to identify the roosting locations of multiple individuals on a daily basis. Therefore, we were able to examine not just the type of roosts but also the distances from the nest to the roost and the exact timing of when females switch from roosting at the nest to roosting away from the nest. We have shown that owls can roost far from their nest and how the age of the nestlings is related to when the female begins roosting away from the box, further highlighting the importance of 
maternal care when nestlings are young and vulnerable. There is still a need for further studies providing basic movement data in order to determine whether movement varies between studies and subspecies.

\section{Declarations}

Acknowledgements Special thanks to Amir Ezer for assisting trapping barn owls. Without him this study would not have been possible.

Funding We would like to thank the Hoopoe Foundation led by Prof. Yossi Leshem for funding the GPS tags. Part of the study was funded by the Addax \& Oryx Foundation (Switzerland) and the Israel Ministry of Science.

Compliance with ethical standards The authors declare that they have no conflict of interest.

\section{References}

Abd Rabou AFN (2020) On the Owls (Order Strigiformes ) Inhabiting the Gaza Strip -Palestine. JOJ Wildl Biodivers 555-603. doi: 10.19080/JOJWB.2020.03.555603

Arrondo E, Moleón M, Cortés-Avizanda A, et al (2018) Invisible barriers: Differential sanitary regulations constrain vulture movements across country borders. Biol Conserv 219:46-52. doi:

10.1016/j.biocon.2017.12.039

Bates D, Maechler M, Bolker B, et al (2019) Linear mixed-effects models using "Eigen" and S4.

Boakye MK, Pietersen DW, Kotzé A, et al (2014) Ethnomedicinal use of African pangolins by traditional medical practitioners in Sierra Leone. J Ethnobiol Ethnomed 10:76. doi: 10.1186/1746-4269-10-76

Boitani L, Ciucci P (2009) Wolf management across Europe: Species Conservation without Boundaries. In: Musiani M, Boitani L, Paquet P (eds) A new era for wolves and people: wolf recovery, human attitudes and policy. University of Calgary Press, pp 15-39

Brooks ME, Kristensen K, van Bentham K, et al (2017) Zero-inflated Generalized Linear Mixed Modeling. R J 9:378-400.

Calenge C (2006) The package "adehabitat" for the R software: A tool for the analysis of space and habitat use by animals. Ecol Modell 197:516-519. doi: 10.1016/j.ecolmodel.2006.03.017

Castañeda XA (2018) Hunting habitat use and selection patterns of barn owl (Tyto Alba) in the urbanagricultural setting of a prominent wine Grape growing region of California. MSc thesis. Humboldt State 
University

Charter M, Izhaki I, Leshem Y, et al (2015) Relationship between diet and reproductive success in the Israeli barn owl. J Arid Environ 122:59-63. doi: 10.1016/j.jaridenv.2015.06.011

Charter M, Izhaki I, Meyrom K, et al (2009) Diets of barn owls differ in the same agricultural region. Wilson J Ornithol 121:378-383. doi: 10.1676/08-083.1

Charter M, Izhaki I, Roulin A (2018) The presence of kleptoparasitic fledglings is associated with a reduced breeding success in the host family in the barn owl. J Avian Biol 49:e01770. doi:

$10.1111 /$ jav.01770

Charter M, Meyrom K, Leshem Y, et al (2010) Does Nest Box Location and Orientation Affect Occupation Rate and Breeding Success of Barn Owls (Tyto alba) in a Semi-Arid Environment? Acta Ornithol 45:115119. doi: $10.3161 / 000164510 \times 516164$

Charter M, Peleg O, Leshem Y, Roulin A (2012) Similar patterns of local barn owl adaptation in the Middle East and Europe with respect to melanic coloration. Biol J Linn Soc 106:447-454. doi: 10.1111/j.10958312.2012.01863.x

Corl A, Charter M, Rozman G, et al (2020) Movement ecology and sex are linked to barn owl microbial community composition. Mol Ecol 29:1358-1371. doi: 10.1111/mec.15398

De Merode E, Homewood K, Cowlishaw G (2004) The value of bushmeat and other wild foods to rural households living in extreme poverty in Democratic Republic of Congo. Biol Conserv 118:573-581. doi: 10.1016/j.biocon.2003.10.005

Ecobichon DJ (2001) Pesticide use in developing countries. Toxicology 160:27-33. doi: 10.1016/S0300$483 \times(00) 00452-2$

Eid E, Handal R (2018) Illegal hunting in Jordan: Using social media to assess impacts on wildlife. Oryx 52:730-735. doi: 10.1017/S0030605316001629

Eisenberg LZ, Caplan N (2003) The Israel-Jordan peace treaty: Patterns of negotiation, problems of implementation. Isr Aff 9:87-110. doi: 10.1080/714003524

Fowler N, Keitt T, Schmidt O, et al (2018) Border wall: bad for biodiversity. Front Ecol Environ 16:137-138. doi: 10.1002/fee.1785

Fry DM (1995) Reproductive effects in birds exposed to pesticides and industrial chemicals. Environ Health Perspect 103:165-171. doi: 10.2307/3432528

Glausiusz J (2018) Owls for peace: how conservation science is reaching across borders in the Middle East. Nature 554:22-23. doi: 10.1038/d41586-018-01388-5 
Gubanyi J, Case R, Wingfield G (1992) Diet and Nesting Success of Barn Owls Breeding in Western Nebraska. Am Midl Nat 127:224-232.

Gustin M, Giglio G, Pelle SC, Frassanito A (2018) Nocturnal flights lead to collision risk with power lines and wind farms in Lesser Kestrels: a preliminary assessment through GPS tracking. Comput Ecol Softw $8: 2-7$.

Hafidzi MN, Hamzah MH (2003) Ranging behaviour of Tyto alba in a ricefield from radio telemetry studies. J Malaysian Appl Biol 32:47-51.

Hegdal, Paul L. Blaskiewicz RW (1984) Evaluation of the Potential Hazard to Barn Owls of Talon Used to Control Rats and House Mice. Environ Toxicol Chem 3:167-179.

Hernández-Pliego J, Rodríguez C, Bustamante J (2017) A few long versus many short foraging trips: Different foraging strategies of lesser kestrel sexes during breeding. Mov Ecol 5:1-16. doi:

$10.1186 / \mathrm{s} 40462-017-0100-6$

Hijmans RJ (2019) Hijmans, Robert J. "Introduction to the" geosphere" package (Version 1.5-10).

Hindmarch S, Elliott JE, Mccann S, Levesque P (2017) Habitat use by barn owls across a rural to urban gradient and an assessment of stressors including, habitat loss, rodenticide exposure and road mortality. Landsc Urban Plan 164:132-143. doi: 10.1016/j.landurbplan.2017.04.003

Kan I, Motro Y, Horvitz N, et al (2014) Agricultural rodent control using barnowls: Is it profitable. Am J Agric Econ 96:733-752. doi: 10.1093/ajae/aat097

Klein Á, Nagy T, Csörgő T, Mátics R (2007) Exterior nest-boxes may negatively affect Barn Owl Tyto alba survival: an ecological trap. Bird Conserv Int 17:263-271. doi: 10.1017/S0959270907000792

Klok C, De Roos AM (2007) Effects of vole fluctuations on the population dynamics of the barn owl Tyto alba. Acta Biotheor 55:227-241. doi: 10.1007/s10441-007-9013-x

Knijnenburg TA, Wessels LFA, Reinders MJT, Shmulevich I (2009) Fewer permutations, more accurate Pvalues. Bioinformatics 25:161-168. doi: 10.1093/bioinformatics/btp211

Korpimäki E (1992) Diet composition, prey choice, and breeding success of Long-eared Owls: Effects of multiannual fluctuations in food abundance. Can J Zool 70:2373-2381. doi: 10.1139/z92-319

Kross SM, Bourbour RP, Martinico BL (2016) Agricultural land use, barn owl diet, and vertebrate pest control implications. Agric Ecosyst Environ 223:167-174. doi: 10.1016/j.agee.2016.03.002

Lambertucci SA, Alarcón PAE, Hiraldo F, et al (2014) Apex scavenger movements call for transboundary conservation policies. Biol Conserv 170:145-150. doi: 10.1016/j.biocon.2013.12.041 
Li F, Zheng X, Jiang XL, Chan BPL (2017) Rediscovery of the sun bear (Helarctos malayanus) in Yingjiang County,Yunnan Province,China. Zool Res 38:206-207. doi: 10.24272/j.issn.2095-8137.2017.044

Liu J, Yong DL, Choi C, Gibson L (2020) Transboundary Frontiers: An Emerging Priority for Biodiversity Conservation. Trends Ecol Evol xx:1-12. doi: 10.1016/j.tree.2020.03.004

Martínez-Padilla J, López-Idiáquez D, López-Perea JJ, et al (2017) A negative association between bromadiolone exposure and nestling body condition in common kestrels: management implications for vole outbreaks. Pest Manag Sci 73:364-370. doi: 10.1002/ps.4435

Martínez JA, López G (1999) Breeding ecology of the Barn Owl (Tyto alba) in Valencia (SE Spain). J Ornithol 99:93-99.

Massa C, Gabelli FM, Cueto GR (2015) using gps tracking to determine movement patterns and foraging habitat selection of the common barn-owl (Tyto alba). Hornero 1:7-12.

Meyrom K, Motro Y, Leshem Y, et al (2009) Nest box use by the barn owl Tyto alba in a biological pest control program in the Beit She'an Valley, Israel. Ardea 97:463-467. doi: 10.5253/078.097.0410

Mitra A, Chatterjee C, Mandal FB (2011) Synthetic chemical pesticides and their effects on birds. Res J Environ Toxicol 5:81-96. doi: 10.3923/rjet.2011.81.96

Naim M, Umar J, Hafidzi MN (2012) The ranging behaviour of Tyto alba in oil palm under baiting with anticoagulant rodenticides, warfarin and brodifacoum and a biorodenticide sarcocystis singaporensis (Zaman \& Colley, 1975). Pertanika J Trop Agric Sci 35:209-221.

Nathan R, Getz WM, Revilla E, et al (2008) A movement ecology paradigm for unifying organismal movement research. Proc Natl Acad Sci 105:19052-19059. doi: 10.1073/pnas.0800375105

Newton I (2010) The Migration Ecology of Birds. Elsevier

Nicolaus LK, Lee H (1999) Low acute exposure to organophosphate produces long-term changes in bird feeding behavior. Ecol Appl 9:1039-1049. doi: 10.1890/1051-0761(1999)009[1039:LAETOP]2.0.CO;2

Oksanen J, Kindt R, Legendre P, et al (2008) The vegan package. Community Ecol Packag 5:190.

Pebesma E, Bivand RS (2005) S Classes and Methods for Spatial Data: the sp Package. Econ Geogr 50:1-21.

Peleg O, Nir S, Meyrom K, et al (2018) Three Decades of Satisfied Israeli Farmers: Barn Owls (Tyto alba ) as Biological Pest Control of Rodents. In: Woods DM (ed) Proc. 28 th Vertebr. Pest Conf. Univ. of Calif., Davis., pp 194-203

Petty SJ, Shaw G, Anderson DIK (1994) Value of nest boxes for population studies and conservation of owls in coniferous forests in Britain. J Raptor Res 28:134-14. 
Ratcliffe D. A. (1970) Changes Attributable to Pesticides in Egg Breakage Frequency and Eggshell Thickness in Some British Birds. J Appl Ecol 7:67-115.

Roulin A (2020) Barn Owls: Evolution and Ecology. Cambridge: Cambridge University Press

Roulin A (2004) The function of food stores in bird nests: Observations and experiments in the barn owl Tyto Alba. Ardea 92:69-78.

Roulin A, Abu Rashid M, Spiegel B, et al (2017) 'Nature Knows No Boundaries': The Role of Nature Conservation in Peacebuilding. Trends Ecol Evol. doi: 10.1016/j.tree.2017.02.018

Rozman G (2020) Factors determining breeding success: the role of life-history traits, movement ecology and sexual segregation during food provisioning in the Barn Owl (Tyto alba). MSc thesis. The Hebrew University of Jerusalem

Santos AA, Santos CAB (2019) Men-fauna relations: drought and bad omen in the northeastern backlands. Int J Dev Res 09:27560-27565.

Séchaud R, Machado AP, Schalcher K, et al (2020) Communally breeding female Barn Owls Tyto alba are not related and do not invest similarly in the communal family invest similarly in the communal family. Bird Study 0:1-4. doi: 10.1080/00063657.2020.1732291

Seel DC, Thomson AG, Turner JCE (1983) Distribution and breeding of the barn owl Tyto alba on Anglesey, North Wales.

Slagsvold T, Sonerud G (2007) Prey size and ingestion rate in raptors: Importance for sex roles and reversed sexual size dimorphism. J Avian Biol 38:650-661. doi: 10.1111/j.2007.0908-8857.04022.x

Sonerud GA, Steen R, Selås V, et al (2014) Evolution of parental roles in provisioning birds: Diet determines role asymmetry in raptors. Behav Ecol 25:762-772. doi: 10.1093/beheco/aru053

Thomas M (2013) Advancing Palestinian Science and Promoting Cooperation under Long-Term Occupation.

Thomsen SK, Kroeger CE, Bloom PH, Harvey AL (2014) Space use and home-range size of barn owls on Santa Barbara Island. Monogr West North Am Nat 7:339-347.

Tompkins EM, Townsend HM, Anderson DJ (2017) Decadal-scale variation in diet forecasts persistently poor breeding under ocean warming in a tropical seabird. PLoS One 12:1-24. doi:

10.1371/journal.pone.0182545

Tucakov M, Kalocsa B, Mikuska T, et al (2006) The Black Stork Ciconia nigra between the Sio channel and the Drava river in the central Danube floodplain: transboundary monitoring and protection plan. Biota 7:109-118. 
Weller A, Orchan Y, Nathan R, et al (2016) Characterizing the Accuracy of a Self-Synchronized ReverseGPS Wildlife Localization System. In: 2016 15th ACM/IEEE International Conference on Information Processing in Sensor Networks, IPSN 2016 - Proceedings.

Wendt CA, Johnson MD (2017) Multi-scale analysis of barn owl nest box selection on Napa Valley vineyards. Agric Ecosyst Environ 247:75-83. doi: 10.1016/j.agee.2017.06.023

Wolf M, Frair J, Merrill E, Turchin P (2009) The attraction of the known: The importance of spatial familiarity in habitat selection in wapiti Cervus elaphus. Ecography (Cop) 32:401-410. doi:

10.1111/j.1600-0587.2008.05626.x

Worton BJ (1989) Kernel methods for estimating the utilization distribution in home- range studies. Ecology 70:164-168. doi: 10.2307/1938423

\section{Tables}

Table 1 Descriptive statistics on the hunting movement and cross border activity of the 15 female barn owls.

\begin{tabular}{|c|c|c|c|c|}
\hline Group & Variable & Mean & SE & Range \\
\hline \multirow{5}{*}{$\begin{array}{l}\text { Hunting } \\
\text { movement }\end{array}$} & Home-range $\left(\mathrm{km}^{2}\right)$ & 9.7 & 1.4 & $1.4-30.1$ \\
\hline & Nightly mean of median displacement (m) & 1140.0 & 192.4 & $\begin{array}{l}29.0- \\
2739.0\end{array}$ \\
\hline & Nightly mean of maximum displacement $(\mathrm{m})$ & 2771.0 & 250.1 & $\begin{array}{l}802.0- \\
4814.0\end{array}$ \\
\hline & Nightly mean of percentage of time hunting (\%) & 70.0 & 4.9 & $23.0-96.0$ \\
\hline & Nightly mean number of hunting trips & 5.4 & 0.5 & $3.3-12.5$ \\
\hline \multirow[t]{5}{*}{$\begin{array}{l}\text { Cross-border } \\
\text { activity }\end{array}$} & Distance of nest to border $(\mathrm{m})$ & 950.0 & 220.0 & $\begin{array}{l}15.0- \\
2580.0\end{array}$ \\
\hline & $\begin{array}{l}\text { Mean percentage of time hunting across border } \\
(\%)\end{array}$ & 23.7 & 6.7 & $0-84.2$ \\
\hline & $\begin{array}{l}\text { Nightly mean of percentage of trips across } \\
\text { border (\%) }\end{array}$ & 16.0 & 2.8 & $0-32.6$ \\
\hline & Percentage of home range across border (\%) & 29.4 & 7.3 & $0-97.0$ \\
\hline & Nightly mean distance of roost to border (m) & 907.0 & 156.0 & $\begin{array}{l}13.0- \\
2342.0\end{array}$ \\
\hline
\end{tabular}


Table 2 Parameter estimates $(\beta)$ from the most parsimonious model showing the hunting movement factors determining reproductive success in 15 female barn owls. Model selection is based on AICc (Akaike Information Criterion) values. See methods for detailed description of procedure.

\begin{tabular}{|lllll|}
\hline Parameter & $\boldsymbol{\beta}$ & SE & $\mathbf{z}$ & $\mathbf{P}$ \\
\hline (Intercept) & 5.088 & 1.518 & 3.351 & $\mathbf{0 . 0 0 1}$ \\
\hline Nightly mean of median distances & 0.002 & 0.001 & 2.579 & $\mathbf{0 . 0 1 0}$ \\
\hline Nightly mean of percentage of time hunting & -0.118 & 0.033 & -3.541 & $<\mathbf{0 . 0 0 1}$ \\
\hline
\end{tabular}

Table 3. Parameter estimates ( $\beta$ ) from the most parsimonious models showing the effect of cross-border activity, hunting movement and breeding variables on diet diversity and percentage of mice in female barn owls. Model selection is based on AIC (Akaike Information Criterion). For tests with diversity as the dependent variable, the AIC is a first order estimate (AIC) and for tests with the percentage of mice as a dependent variable, the $\mathrm{AIC}$ is a second order estimate $\left(\mathrm{AIC}_{\mathrm{C}}\right)$. See methods for detailed description of procedure. 


\begin{tabular}{|c|c|c|c|c|c|c|}
\hline $\begin{array}{l}\text { Dependent } \\
\text { variable }\end{array}$ & Topic & Parameter & $\beta$ & SE & Statistic ${ }^{a}$ & $\mathbf{p}$ \\
\hline \multirow{7}{*}{$\begin{array}{l}\text { Diet diversity } \\
\text { (Shannon } \\
\text { Diversity Index) }\end{array}$} & \multirow{3}{*}{$\begin{array}{l}\text { Cross- } \\
\text { border } \\
\text { activity }\end{array}$} & (Intercept) & 0.798 & 0.173 & 4.601 & $<0.001$ \\
\hline & & $\begin{array}{l}\text { Nightly mean } \\
\text { percentage of cross- } \\
\text { border trips }\end{array}$ & -0.018 & 0.013 & -1.388 & 0.165 \\
\hline & & $\begin{array}{l}\text { Nightly mean } \\
\text { percentage of time } \\
\text { hunting cross-border }\end{array}$ & 0.010 & 0.006 & 1.672 & 0.094 \\
\hline & \multirow{2}{*}{$\begin{array}{l}\text { Hunting } \\
\text { movement }\end{array}$} & (Intercept) & -0.038 & 0.397 & -0.096 & 0.924 \\
\hline & & $\begin{array}{l}\text { Nightly mean number } \\
\text { of trips }\end{array}$ & 0.166 & 0.074 & 2.249 & 0.025 \\
\hline & \multirow[t]{2}{*}{ Breeding } & (Intercept) & -62.293 & 73.286 & -0.850 & 0.395 \\
\hline & & Laying date & 0.004 & 0.004 & 0.860 & 0.390 \\
\hline \multirow[t]{4}{*}{ Percentage mice } & \multirow{2}{*}{$\begin{array}{l}\text { Cross- } \\
\text { border } \\
\text { activity }\end{array}$} & (Intercept) & 0.589 & 0.462 & 1.273 & 0.203 \\
\hline & & $\begin{array}{l}\text { Nightly mean } \\
\text { percentage of cross- } \\
\text { border trips }\end{array}$ & -0.060 & 0.023 & -2.585 & 0.010 \\
\hline & \multirow{2}{*}{$\begin{array}{l}\text { Hunting } \\
\text { movement }\end{array}$} & (Intercept) 1 & -3.880 & 1.186 & -3.272 & 0.001 \\
\hline & & $\begin{array}{l}\text { Nightly mean number } \\
\text { of trips }\end{array}$ & 0.704 & 0.230 & 3.065 & 0.002 \\
\hline
\end{tabular}

aThe statistic in models including diet diversity as a dependent variable was a t-value and in all other models the statistic was a z-value.

Table 4. Results from the LMM (Linear Mixed Model) and GLMMTMB (Generalized Linear Mixed Models using Template Model Builder) analysis showing the factors affecting diet (diversity, percentage voles and percentage mice) in barn owls ( $n=15$ females from 2 years). The table shows variables included in the models. Model selection is based on AIC (Akaike Information Criterion). $K=$ number of estimable parameters in the models; $\Delta_{i}=\mathrm{AlC}_{(\mathrm{i})}-\mathrm{AlC}_{(\mathrm{min})}$. The most parsimonious model is highlighted in bold (see Methods for detailed description of procedure). For tests with diversity as the dependent variable, the AIC is a first order estimate (AIC) and for tests with the percentage of voles and mice as dependent variables, the AIC is a second order estimate $\left(\mathrm{AIC}_{\mathrm{C}}\right)$. The most parsimonious models are in bold. 


\begin{tabular}{|c|c|c|c|c|c|}
\hline $\begin{array}{l}\text { Dependent } \\
\text { variable }\end{array}$ & Topic & Models & K & AIC & $\Delta_{i}$ \\
\hline \multirow[t]{12}{*}{$\begin{array}{l}\text { Diet diversity } \\
\text { (Shannon } \\
\text { Diversity Index) }\end{array}$} & \multirow[t]{6}{*}{$\begin{array}{l}\text { Cross- } \\
\text { border } \\
\text { activity }\end{array}$} & $\begin{array}{l}\text { Nightly mean percentage of trips across } \\
\text { the border + Nightly mean percentage of } \\
\text { hunting across the border }\end{array}$ & 5 & 22.057 & 0.000 \\
\hline & & $\begin{array}{l}\text { Nightly mean percentage of hunting } \\
\text { across the border }\end{array}$ & 4 & 22.291 & 0.234 \\
\hline & & $\begin{array}{l}\text { Percentage of home-range across the } \\
\text { border }\end{array}$ & 4 & 22.315 & 0.258 \\
\hline & & $\begin{array}{l}\text { Nightly mean percentage of trips across } \\
\text { the border }\end{array}$ & 4 & 23.199 & 1.143 \\
\hline & & $\begin{array}{l}\text { Nightly mean percentage of trips across } \\
\text { the border }+ \text { Percentage of home-range } \\
\text { across the border }\end{array}$ & 5 & 23.628 & 1.571 \\
\hline & & $\begin{array}{l}\text { Nightly mean percentage of hunting } \\
\text { across the border + Percentage of home- } \\
\text { range across the border }\end{array}$ & 5 & 24.020 & 1.963 \\
\hline & \multirow{3}{*}{$\begin{array}{l}\text { Hunting } \\
\text { movement }\end{array}$} & Nightly mean number of trips & 4 & 20.027 & 0.000 \\
\hline & & $\begin{array}{l}\text { Nightly mean median distance }+ \text { Nightly } \\
\text { mean number of trips }\end{array}$ & 5 & 21.913 & 1.886 \\
\hline & & $\begin{array}{l}\text { Nightly mean number of trips + Nightly } \\
\text { mean percentage time hunting }\end{array}$ & 5 & 21.939 & 1.912 \\
\hline & \multirow{3}{*}{$\begin{array}{l}\text { Breeding } \\
\text { variables }\end{array}$} & Laying date & 4 & 22.534 & 0.000 \\
\hline & & Number of fledglings & 4 & 22.802 & 0.268 \\
\hline & & Laying date + Number of fledglings & 5 & 24.395 & 1.861 \\
\hline $\begin{array}{l}\text { Percentage of } \\
\text { voles }^{\text {a }}\end{array}$ & $\begin{array}{l}\text { Hunting } \\
\text { movement }^{b}\end{array}$ & $\begin{array}{l}\text { Nightly mean median distance }+ \text { Nightly } \\
\text { mean number of trips }\end{array}$ & 5 & -3.099 & 0.397 \\
\hline $\begin{array}{l}\text { Percentage of } \\
\text { mice }^{c}\end{array}$ & $\begin{array}{l}\text { Hunting } \\
\text { movement }\end{array}$ & Nightly mean number of trips & 4 & -0.251 & 0.000 \\
\hline
\end{tabular}

${ }^{a}$ For percentage of voles in the diet and cross-border activity, the most parsimonious model included just the intercept and no other models had a $\triangle \mathrm{AIC}<2$.

${ }^{\mathrm{b}}$ For percentage of voles and hunting movement, the most parsimonious model included just the intercept. For percentage of voles and breeding variables, the most parsimonious model included just the intercept and no other models had a $\triangle \mathrm{AIC}<2$.

${ }^{\mathrm{C}}$ For percentage of mice and cross-border activity, the most parsimonious model included just the intercept and no other models had a $\triangle \mathrm{AIC}<2$. For percentage of mice and breeding variables, the most 
parsimonious model included just the intercept and no other models had a $\Delta \mathrm{AIC}<2$.

\section{Appendix}

In order to build a null model to test whether owls crossed the border more or less than expected if they were hunting in random directions, we conducted a permutation analysis: (1) we randomly selected four nights and eight hours per night for each owl, (2) we calculated the observed proportion of hourly maximal distance localizations that were in Israel and across the border for the 15 owls combined, (3) we built a distribution of hourly maximal distances from the observed tracking data, (4) for each owl, maximal distance points were randomly selected from the maximal distance distribution and projected in a random direction from the individual's nest, (5) the same number of points were projected as the tracking hours in the observed data and the random points were overlaid onto the territory polygons to determine whether they were across the border or not, (6) we calculated the randomly generated proportion of hourly maximal distance localizations that were in Israel and across the border for all the owls combined. This step was repeated 1000 times in order to build a distribution of the proportion of the randomly generated points across the border. (7) We then checked where the observed proportion fell within the permuted distribution of proportions and calculated the $p$-value by using the equation (Knijnenburg et al. 2009):

$$
P_{P_{\text {erm }}}=\left(1+\sum_{n=1}^{N}(P \leq O)\right) /(\mathrm{N}+1)
$$

where $\mathrm{P}=$ the proportions from the permuted data, $\mathrm{O}=$ the proportion from the observed data and $\mathrm{N}=$ the number of permutations. The summation of the $\mathrm{P} \leq \mathrm{O}$ is the number of times the permuted proportions were less than and equal to the observed proportion. Using the same method, we checked for cases in which the permuted proportions were greater than or equal to the observed.

\section{Figures}




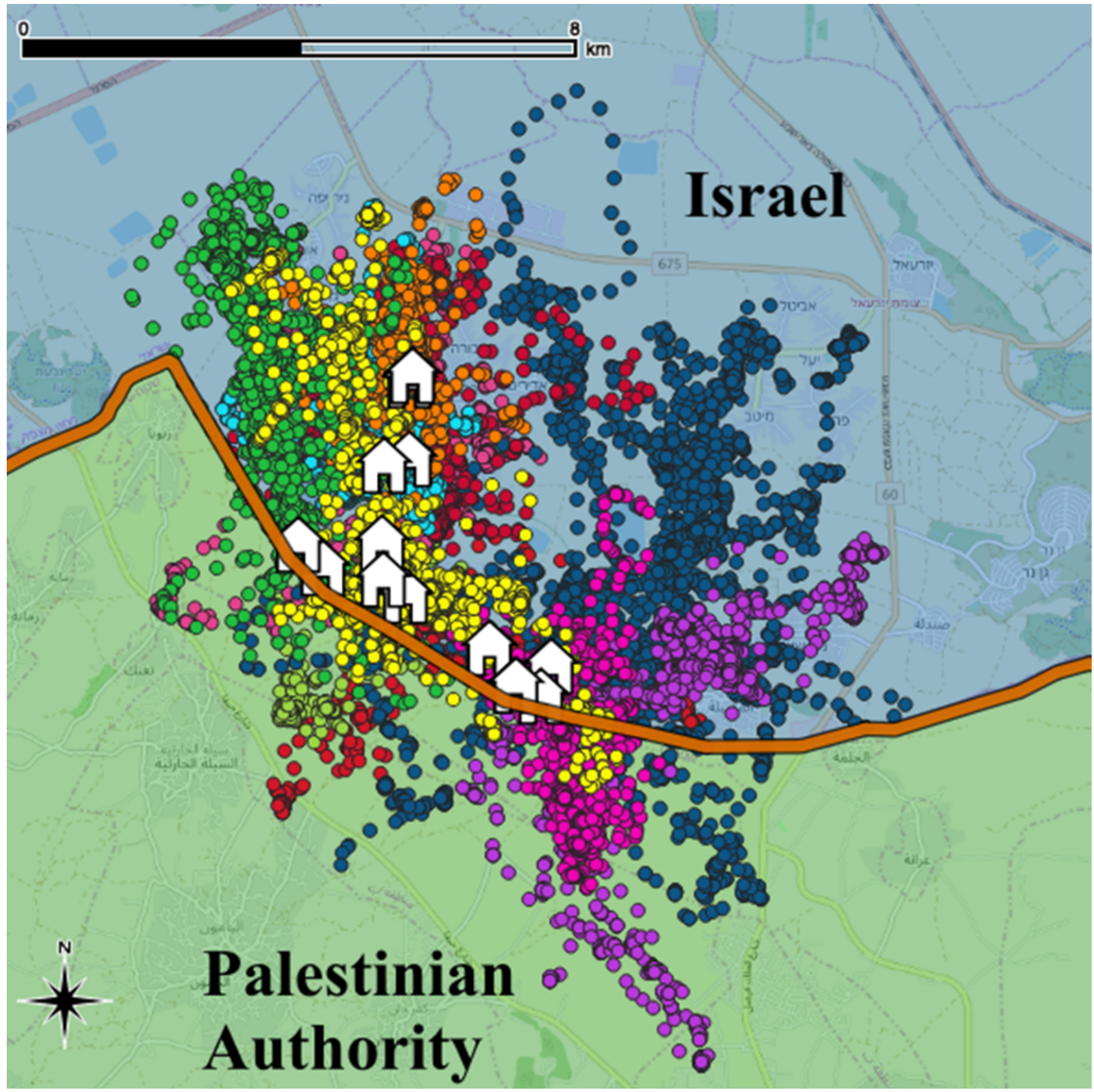

Figure 1

The movement data of 12 female barn owls. White house icons represent the owl nest boxes. 


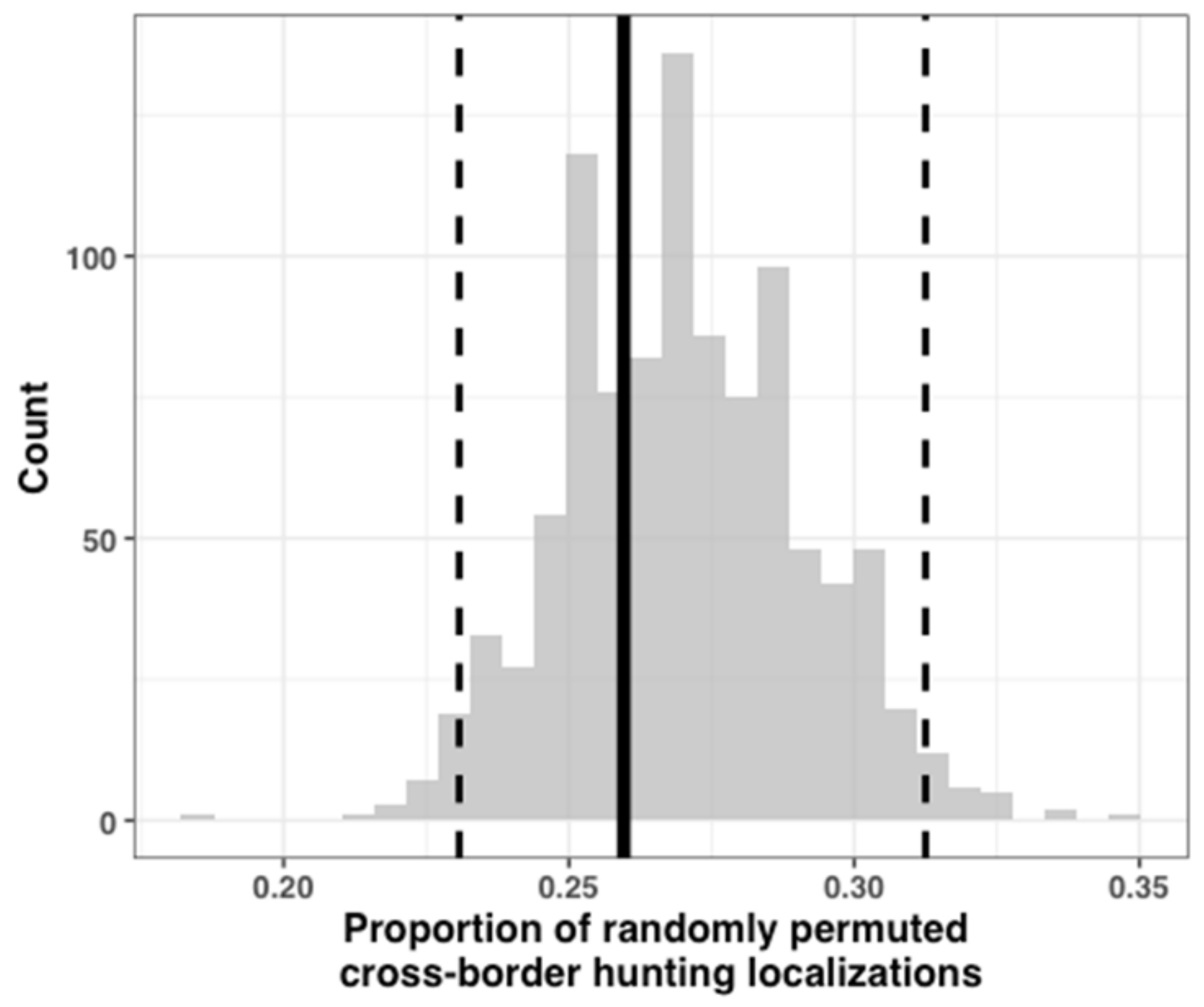

Figure 2

Barn owls cross borders as expected randomly (Permutation analysis $p=0.34$ ). The grey bars represent the distribution of the proportion of hourly maximal distance points that were across the border from the permutated data. The dashed lines represent the lower and upper quantiles and the solid line represents the observed proportion of hourly maximal distance points that were across the border. The observed statistic falls within the lower and upper quartiles, indicating no significant difference with the random distribution. 